\title{
IMPLEMENTASI KEGIATAN MENGHAFAL AL-QURAN SISWA DI LPTQ KABUPATEN SIAK
}

\author{
Iwan Agus Supriono \\ Sekolah Tinggi Agama Islam Sultan Syarim Hasyim Siak Sri Indrapura \\ Jl. Raudatul Tullab, Nomor 18 ,Desa Kampung Tengah Kecamatan, Benteng \\ Hulu, Mempura, Benteng Hulu, Mempura, Kabupaten Siak, Riau 28773 \\ Email: iwanagus484@yahoo.co.id
}

\author{
Atik Rusdiani \\ Universitas Lampung \\ Jl. Prof. Dr. Ir. Sumantri Brojonegoro, RW.No: 1, Gedong Meneng, \\ Kec. Rajabasa, Kota Bandar Lampung, Lampung 35141 \\ Email: atik.rusdiani@gmail.com
}

\begin{abstract}
ABSTRAK
Fokus penelitian yang akan diuji dalam penelitian adalah proses menghafal AlQuran di LPTQ Kabupaten Siak. Pendekatan penelitian yang digunakan adalah penelitian kualitatif. Metode penelitian menggunakan metode deskriptif. Teknik Pengumpulan data menggunakan teknik observasi partisipan, wawancara mendalam, dan dokumentasi. Analisis data diproses melalui reduksi data, penyajian data, dan verifikasi. Pengecekan keabsahan data menggunakan teknik credibility, confirmability, transferability, dan dependenbility. Hasil penelitian menyimpulkan bahwa proses menghafal Al-Quran di LPTQ Kabupaten Siak, menggunakan sistem One Day One Ayah (1 hari 1 ayat) yang disertai lagu tartil. Proses menghafal Al-Quran selalu diiringi niat yang ikhlas, meminta izin kepada orang tua, mempunyai tekad yang besar dan kuat, dan istiqamah sampai lancar membaca Al-Quran. Metode yang digunakan untuk menghafal Al-Quran adalah dengan muraja'ah 'setoran hafalan baru' kepada guru (ustadz/ustadzah), dan muraja'ah hafalan lama yang disemakkan teman dengan berhadapan dua orang dua orang, muraja'ah hafalan lama kepada ustadz/ustadzah, dan Al-Imtihan Fii Muraja'atil Muhafadlah (ujian mengulang hafalan).
\end{abstract}

Kata kunci: Implementasi, Menghafal, Al-Quran

\section{ABSTRACT}

The focus of the research to be tested in research is the process of memorizing the Quran in LPTQ Kabupaten Siak. The research approach used is qualitative research. The research methods used is desciptive. Data collection uses the techniq of participant observation, in-depth interviews and documentation, using analysis of data reduction, data presentation, and verification. This study also 
checks the validity of the data by using the techniques of credibility, confirmability, transferability, and dependenbility. The process of memorizing the Quran in LPTQ Kabupaten Siak using the One Day One Ayah system (1 day 1 verse) accompanied by tartil songs. In memorizing the Quran, of course, it must always be accompanied by sincere intentions, asking permission from parents, having a big and strong determination, istiqamah, till fluently reading the Quran.

Key Words: Implementation, Memorizing, the Quran

\section{PENDAHULUAN}

Al-Quran adalah kalamullah yang merupakan mu'jizat yang diturunkan kepada Nabi Muhammad saw dan membacanya merupakan suatu ibadah. AlQuran menempati posisi sebagai sumber pertama dan utama dari seluruh ajaran Islam. Al-Quran berfungsi sebagai petunjuk atau pedoman bagi umat manusia dalam mencapai kebahagiaan di dunia maupun di akhirat. Pada masa Nabi Muhammad saw bangsa Arab sebagian besar buta huruf. Mereka belum banyak mengenal kertas sebagai alat tulis seperti sekarang. Oleh karena itu setiap Nabi menerima wahyu selalu dihafalnya, kemudian beliau sampaikan kepada para sahabat dan para sahabat diperintahkan untuk menghafalkan AlQuran dan menuliskan di batu-batu, pelepah kurma, kulit-kulit binatang dan apa saja yang bisa dipakai untuk menulisnya (Zen, 1985).

Al-Quran layaknya sebuah permata yang memancarkan cahaya yang berbeda-beda sesuai dengan sudut pandang masing-masing (Shihab, 2003). Hidup di bawah naungan Al-Quran adalah nikmat yang tidak dapat diketahui kecuali oleh orang yang merasakannya, demikian kata Sayid Qutub dalam mukaddimah tafsirnya Fi Dzilal al- Quran. Mempelajari Al-Quran bukan hanya susunan redaksi dan pemilihan kosakata, tetapi juga kandungannya yang tersurat, tersirat, bahkan sampai kesan yang ditimbulkannya. Semua dituangkan dalam jutaan jilid buku, berlangsung generasi demi generasi. Dalam proses pembelajaran siswa dituntut agar dapat memahami materi pelajaran yang diberikan. Kemampuan dan tingkat pengetahuan setiap siswa tidak sama satu dengan yang lainnya. Selain itu, ada anggapan siswa bahwa mata pelajaran rumit dan terlalu sulit sehingga menyebabkan siswa tidak memerhatikan ketika proses pembelajaran berlangsung. Ketuntasan belajar siswa tidak memenuhi kriteria yang ditetapkan oleh sekolah. Hal tersebut menyebabkan keinginan siswa untuk belajar menjadi berkurang. Hasil belajar siswa berbeda-beda sesuai dengan perbedaan kemampuan dan kecenderungan.

Hafal Al-Quran bukan hal yang impossible 'mustahil'. Menghafal AlQuran merupakan ibadah yang sangat dianjurkan. Bagi orang Islam yang ingin melakukannya, Allah telah memberi garansi akan mudahnya menghafal AlQuran. Dorongan untuk menghafal Al-Quran telah dijelaskan dalam Al-Quran dan hadis. Allah SWT berfirman: "Dan sesungguhnya, telah kami mudahkan AlQuran untuk peringatan maka adakah orang yang mengambil pelajaran ?"(Q.S. Al-Qamar ayat 22). Ayat tersebut mengindikasikan kemudahan menghafalkan Al-Quran. Menghafalkan Al-Quran hukumnya fardu kifayah. Artinya tidak semua 
orang Islam diwajibkan menghafal Al-Quran. Kewajiban ini sudah cukup terwakili dengan adanya beberapa orang yang mampu menghafalkannya (Zawawie, 2011)

Menghafal Al-Quran merupakan suatu aktifitas yang sangat mulia dimata Allah Swt, menghafal AI-Quran sangat berbeda dengan menghafal kamus atau buku, dalam menghafal Al-Quran harus benar tajwid dan fasih dalam melafalkanya. Jika penghafal Al-Quran belum bisa membaca dan belum mengetahui tajwidnya maka akan susah dalam menghafal Al Qur'an (Keswara, 2017)

Salah satu cara menjaga kelestarian Al-Quran adalah dengan menghafalkannya, karena memelihara kesucian dengan menghafalkannya adalah pekerjaan yang terpuji dan amal yang mulia, yang sangat dianjurkan Rasulullah. Rasulullah dan para sahabat banyak yang hafal Al-Quran. Hingga sekarang tradisi menghafal AI-Quran masih dilakukan oleh umat Islam di dunia (Syamsudin, 2001).

Melestarikan (menjaga) Al-Quran dilakukan dengan menghafalnya agar tetap terjaga dalam dada. untuk melestarikan hafalan diperlukan kemauan yang kuat dan istiqamah yang tinggi. Metode muraja'ah adalah metode mengulang hafalan, baik hafalan baru maupun hafalan lama yang disampaikan kepada orang lain. Dalam hal ini santri dapat memperdengarkan muraja'ah hafalannya kepada Ustadz/Ustadzah, santri maupun masyarakat. Metode ini sangat membantu karena kalau mengulang sendiri terdapat kesalahan yang tidak disadari. Akan berbeda jika melibatkan partner/guru, kesalahan-kesalahan yang terjadi akan mudah diketahui dan kemudian diperbaiki. Yang belum diketahui disini adalah bagaimana pelaksanaan metode tersebut, apakah sudah dapat membantu dalam menghafal Al-Quran santri.

Untuk mencapai tujuan belajar di LPTQ Kabupaten Siak, setiap siswa akan selalu berusaha supaya tujuan belajarnya tercapai yaitu dengan belajar tekun. Lingkungan sekolah tidak lepas dari masyarakat. Sekolah didirikan oleh masyarakat untuk mendidik anak menjadi warga negara yang berguna dalam masyarakat. Selain itu, masyarakat atau lingkungan menjadi laboratorium dan sumber yang penuh dengan kemungkinan untuk memperkaya pengajaran. Oleh karena itu, setiap guru harus mengenal masyarakat dan lingkungannya dan menggunakannya secara fungsional dalam pengajaran terhadap siswa yang beraneka macam kemampuannya. Hal tersebut bertujuan agar siswa dapat belajar dengan nyaman dan mencapai tujuan belajar dengan baik. Keberhasilan belajar siswa tidaklah lepas dari beberapa faktor yang mempengaruhi, di antaranya faktor guru dan faktor siswa. Guru merupakan pengelola belajar atau yang disebut pembelajar.

\section{METODE}

Pendekatan penelitian yang digunakan adalah penelitian kualitatif. Metode penelitian menggunakan metode deskriptif. Teknik Pengumpulan data menggunakan teknik observasi partisipan, wawancara mendalam, dan dokumentasi. Analisis data diproses melalui reduksi data, penyajian data, dan verifikasi. Pengecekan keabsahan data menggunakan teknik credibility, confirmability, transferability, dan dependenbility. 


\section{HASIL DAN PEMBAHASAN Menghafal Al-Quran}

Tahfidz al-Quran terdiri dari dua kata yaitu tahfidz dan al-Quran. Kata tahfidz merupakan bentuk masdar ghoiru mim dari kata : تحفيظا يحفظ حفظ yang mempunyai arti menghafalkan. Tahfidz atau menghafal Al-Quran merupakan suatu perbuatan yang sangat mulia dan terpuji. Orang yang menghafal AlQuran merupakan salah satu hamba yang ahlullah di muka bumi. Pengertian Tahfidz yaitu menghafal materi baru yang belum pernah dihafal (Zen, 1985).

Pelaksanaan program Tahfidzul Quran dapat dilakukan dengan beberapa metode yang menyenangkan salah satunya yaitu dengan mendengarkan mp3 Al-Quran atau video-video hafalan Al-Quran. Sehingga santri-santri dalam menghafal Al-Quran tidak terus menerus hanya melihat, mengingat lalu menghafal. Selanjutnya langkah yang terakhir dari manajemen adalah evaluasi, evaluasi berfungsi sebagai informasi hasil pembelajaran program tahfidz yang sedang atau telah dilaksanakan. Dalam Sisdiknas No. 20 tahun 2003 Bab XVI pasal 57 ayat 1 dan pasal 58 ayat 8, menyatakan: Evaluasi dilakukan dalam rangka pengendalian mutu pendidikan secara nasional sebagai bentuk akuntabilitas penyelenggara pendidikan kepada pihak-pihak yang berkepentingan. Evaluasi hasil belajar peserta didik dilakukan oleh pendidik untuk memantau proses, kemajuan, dan perbaikan hasil belajar secara berkesinambungan (Keswara, 2017).

Dalam menghafal Al-Qur'an, ada dua hal pokok yang senantiasa dilaksanakan, yaitu menambah dan menjaga hafalan. Masing-masing santri minimal harus menambah hafalan sebanyak satu halaman dalam sehari. Aktivitas menambah hafalan lebih sering dilaksanakan setelah qiyamullail sampai menjelang waktu sholat subuh, yang mana hal ini juga telah dipersiapkan sedari sebelum tidur. Adapun aktivitas menjaga hafalan lebih banyak dilakukan, mengingat bahwa menjaga hafalan lebih sulit jika dibandingkan dengan aktivitas menambah hafalan (Fajarini, Sutoyo, \& Sugiharto, 2017).

Keinginan cepat khatam 30 juz memang sangatlah wajar dalam proses menghafal Al-Quran. Namun, jangan sampai keinginan tersebut membuat penghafal terburu-buru dalam menghafalkan Al-Quran dan pindah kehafalan baru. Sebab, bila penghafal berpikir demikian, dikhawatirkan akan melalaikan hafalan yang sudah pernah dihafal tidak diulang kembali karena penghafal lebih fokus pada hafalan baru dan tidak men-takrir (menjaga/mengulang) hafalan yang lama- (Ra'uf \& Al-Hafidz, 2009). Cara mengulang hafalan yang baik, hendaknya penghafal mengulang yang sudah dihafalkan atau sudah disetorkan kepada guru atau kyai secara terus-menerus dan istiqamah. Tujuan Takrir atau mengulang ialah supaya hafalan yang sudah dihafalkan tetap terjaga dengan baik, kuat, dan lancar. Mengulang hafalan bisa dilakukan oleh sendiri, didengarkan oleh guru, atau teman. Pada umumnya, seorang guru membagi waktu kegiatan menyetor hafalan Al-Quran. Waktu untuk menyetor hafalan yaitu pagi hari dan waktu sore setelah Ashar atau setelah Maghrib.

\section{Konsep Menghafal Al-Quran}

Menghafal Al-Qur'an merupakan aktivitas yang dipenuhi dengan upayaupaya yang mengharuskan penghafalnya untuk senantiasa konsisten. Upaya 
faktual yang dilakukan oleh para santri penghafal Al-Qur'an untuk memperkuat hafalan Al-Qur'an dapat dikategorikan sesuai indikator sebagai berikut: (a) konsentrasi, (b) pola makan, (c) kehidupan sosial, dan (d) ibadah. Ragam upaya tersebut dapat melatih para santri untuk menjadi disiplin, sehingga aktivitas menghafal Al-Qur'an dapat dilakukan secara terjadwal dan berkesinambungan (Fajarini, Sutoyo, \& Sugiharto, 2017).

Faktor-faktor yang mempengaruhi kualitas menghafal, menurut Putra dan Issetyadi dalam Saptadi (2012) berasal dari faktor internal dan eksternal. Faktor internal antara lain kondisi emosi, keyakinan/belief, kebiasaan/habit, dan cara memproses stimulus. Sedangkan yang termasuk faktor eksternal adalah lingkungan belajar dan nutrisi tubuh. Namun faktor - faktor yang dapat mendukung dan meningkatkan kemampuan seseorang dalam menghafal AlQuran menurut Alfi dalam Saptadi (2012) antara lain adalah: 1) motivasi dari penghafal; 2) mengetahui dan memahami arti atau makna yang terkandung dalam Al-Quran; 3) pengaturan dalam menghafal; 4) fasilitas yang mendukung; 5) otomatisasi hafalan; dan 6) pengulangan hafalan.

Sebelum memulai menghafal Al-Qur'an, terlebih dahulu santri membaca mushaf Al-Quran dengan Binadhor 'melihat ayat AI-Quran' dihadapan guru atau kyai. Sebelum memperdengarkan dengan hafalan yang baru, terlebih dahulu penghafal Al-Quran menghafal sendiri materi yang akan disemak dihadapan guru atau kyai dengan jalan sebagai berikut: pertama kali terlebih dahulu calon penghafal membaca dengan melihat mushaf (Binadhor) materi-materi yang akan diperdengarkan dihadapan guru atau kyai minimal 3 (tiga) kali. Setelah dibaca dengan melihat mushaf (Binadhor) dan terasa ada bayangan, lalu dibaca dengan hafalan (tanpa melihat mushaf atau Bilghoib) minimal 3 (tiga) kali dalam satu kalimat dan maksimalnya tidak terbatas. Apabila sudah dibaca dan dihafal 3 (tiga) kali masih belum ada bayangan atau masih belum hafal, maka perlu ditingkatkan sampai menjadi hafal betul dan tidak boleh menambah materi yang baru. Setelah satu kalimat tersebut ada dampaknya dan menjadi hafal dengan lancar, lalu ditambah dengan merangkaikan kalimat berikutnya sehingga sempurna satu ayat. Materi-materi baru ini selalu dihafal sebagaimana halnya menghafal pada materi pertama kemudian dirangkaikan dengan mengulang-ulang materi atau kalimat yang telah lewat, minimal 3 (tiga) kali dalam satu ayat ini dan maksimal tidak terbatas sampai betul-betul hafal. Tetapi apabila materi hafalan satu ayat ini belum lancar betul, maka tidak boleh pindah ke materi ayat berikutnya (Wahid, 2012)

\section{Metode Tahfidz Al-Quran}

Sebenarnya banyak sekali metode khusus dalam menghafal Al-Quran. Namun, dalam buku Mukhlisoh Zawawie hanya akan menguraikan beberapa metode yang paling banyak dilakukan dan berhasil mencetak Huffazh. Oleh karena itu, para pencinta Al-Quran yang ingin menghafalkan Al-Quran bisa memilih metode yang paling cocok untuk dirinya, atau bisa juga menggabungkan antara satu metode dengan lainnya sehingga akan lebih memperkuat hafalan yang telah dicapai. Metode-metode tersebut yaitu menghafal sendiri, menghafal berpasangan, menghafal dengan bantuan AlQuran digital, menghafal dengan alat perekam, dan metode menghafal dengan menulis. 
Metode menghafal sendiri merupakan metode mengulang sendiri yang paling banyak dilakukan karena masing-masing Huffazh bisa memilih yang paling sesuai untuk dirinya tanpa harus menyesuaikan diri dengan orang lain. Metode ini bisa dilakukan dalam beberapa model, yaitu: 1) Tasdis Al-Quran, adalah mengulang hafalan Al-Quran dengan menghatamkannya dalam waktu enam hari. Setiap hari mengulang lima juz hafalan. Metode ini adalah metode yang paling baik, karena dalam waktu sebulan bisa menghatamkan Al-Quran sebanyak lima kali. Karena itulah tidak berlebihan jika sebagian ulama berkata: "Barang siapa yang membiasakan dirinya mengulang hafalan Al-Quran 5 juz setiap hari, pasti ia tidak akan lupa"; 2) Tasbi' Al-Qur'an, metode ini sangat terkenal dikalangan para ulama salaf dan paling banyak diberlakukan di pondok-pondok Tahfidz al-Qur'an, terutama bagi para Haffizh yang baru selesai menghatamkan hafalannya. Metode ini dilakukan dengan membagi Al-Quran menjadi tujuh bagian. Lalu, mengulang tiap-tiap bagian setiap hari sehingga dalam waktu satu minggu Al-Quran bisa dihatamkan secara keseluruhan. Dengan demikian dalam waktu satu bulan Hufazh bisa mengkhatamkan AlQuran sebanyak empat kali. Sebagaimana telah disebutkan di awal, Tasbi' AlQuran ini merupakan rutinitas yang banyak dipraktikkan oleh para sahabat dan Nabi Muhammad SAW (Zawawie, 2011).

Metode yang kedua adalah menghafal berpasangan, metode ini dilakukan oleh dua orang Huffazh secara bersama-sama. Hafalan dimulai setelah mereka menyepakati ayat-ayat yang akan dihafalkan. Langkah-langkah yang ditempuh dalam metode ini adalah: 1) memilih kawan menghafal yang cocok dan menentukan surat serta waktu yang telah disepakati bersama; 2) saling membuka mushaf Al-Quran pada bagian ayat yang akan dihafalkan, lalu salah satu dari keduanya membaca ayat tersebut, sedangkan yang lain mendengarkan dengan serius dan berusaha merekam bacaan di dalam otaknya. Setelah selesai, kawan yang tadinya mendengarkan ganti membaca mushaf yang dipegangnya, sementara yang lain mendengar dengan sungguhsungguh. Setelah itu, yang jadi pendengar mengulang ayat tersebut tanpa melihat. Kemudian kawan yang satunya juga melakukan hal yang sama. Proses ini diulang beberapa kali sampai keduanya yakin telah berhasil menghafal ayat tersebut; 3) dilanjutkan dengan praktik tarabbuth, yaitu menyambung ayat-ayat yang telah berhasil dihafalkan; 4) terakhir, saling menguji hafalan di antara keduanya.

Metode yang ketiga adalah menghafal dengan bantuan Al-Quran digital. Metode dapat kita lakukan dengan menggunakan pocket Al-Quran atau Al-Quran digital yang telah dirancang secara khusus. Kita bisa memilih ayat yang kita kehendaki dan mendengarkannya secara berulang-ulang. Lalu, berusaha mengikutinya sampai benar-benar hafal kemudian baru berpindah pada ayat seterusnya. Setelah benar-benar yakin hafal, coba ulangi sendiri tanpa bantuan Al-Quran digital.

Metode yang keempat yaitu menghafal dengan alat perekam. Metode ini diawali dengan merekam suara sendiri yang sedang membaca beberapa ayat yang kita kehendaki. Selanjutnya, aktifkan alat tersebut dan berusaha mengikuti bacaan-bacaan dalam rekaman tersebut sampai benar-benar hafal. Setelah itu, kita mencoba mengulang hafalan tanpa bantuan alat perekam. 
Metode yang kelima adalah metode menghafal dengan menulis. Metode ini banya dilakukan di pondok pesantren yang mendidik calon-calon Huffazh yang masih kecil, tetapi sudah bisa membaca dan menulis dengan benar. Tahapan-tahapan dalam metode ini adalah guru Huffazh menuliskan beberapa ayat di papan tulis, lalu menyuruh anak didiknya menulis dengan benar ayat tersebut. Setelah itu, guru mengoreksi satu per satu tulisan anak didiknya. Kemudian, guru membacakan denga tartil dengan tulisan di papan tulis dan menyuruh anak didiknya mengikuti dan mengulanginya secara bersama-sama. Dilanjutkan dengan langkah menghafal. Guru menghapus tulisan di papan tulis dan menyuruh masing-masing anak didik mencoba menghafal dengan melihat tulisan yang ada di buku mereka. Selanjutnya, masing-masing anak didik disuruh menutup buku mereka dan menghafal dengan tanpa melihat sampai benar-benar hafal. Langkah terakhir, masing-masing anak didik disuruh menulis lagi ayat yang telah mereka hafalkan dalam buku mereka dengan tanpa melihat tulisan mereka yang pertama, kemudian guru mengecek hasil tulisan tersebut. Jika tidak ditemukan kesalahan, baru anak didik dianggap lulus dalam hafalannya.

\section{Menjaga menghafal Al-Qur'an}

Takrir yaitu mengulang hafalan yang sudah diperdengarkan kepada guru atau kyai. Hafalan yang sudah diperdengarkan kehadapan guru atau kyai yang semula sudah dihafal dengan baik dan lancar, kadangkala masih terjadi kelupaan lagi bahkan kadang-kadang menjadi hilang sama sekali. Oleh karena itu perlu diadakan takrir atau mengulang kembali hafalan yang telah diperdengarkan kehadapan guru atau kyai.

Manusia tidak dapat dipisahkan dengan sifat lupa, karena lupa merupakan identitas yang selalu melekat dalam dirinya. Dengan pertimbangan inilah, agar hafalan Al-Qur'an yang telah dicapai dengan susah payah tidak hilang, mengulang hafalan dengan teratur adalah cara terbaik untuk mengatasinya. Ada dua macam metode pengulangan, yaitu : pertama, mengulang dalam hati. Ini dilakukan dengan cara membaca Al-Qur'an dalam hati tanpa mengucapkannya lewat mulut. Metode ini merupakan salah satu kebiasaan para ulama dimasa lampau untuk menguatkan dan mengingatkan hafalan mereka. Dengan metode ini pula, seorang Huffazh akan terbantu mengingat hafalan-hafalan yang telah ia capai sebelumnya. Kedua, mengulang dengan mengucapkan. Metode ini sangat membantu calon Huffazh dalam memperkuat hafalannya. Dengan metode ini, secara tidak langsung ia telah melatih mulut dan pendengarannya dalam melafalkan serta mendengarkan bacaan sendiri. la pun akan bertambah semangat dan terus berupaya melakukan pembenaran-pembenaran ketika terjadi salah pengucapan.

Mengulang atau takrir materi yang sudah dihafal ini biasanya agak lama juga, walaupun kadang-kadang harus menghafal lagi materi-materi ini tetapi tidak sesulit menghafal materi baru. Disamping itu, fungsi dari mengulang-ulang hafalan yang sudah disetorkan kepada guru atau kyai adalah untuk menguatkan hafalan itu sendiri dalam hati penghafal, karena semakin sering dan banyak penghafal mengulang hafalan, maka semakin kuat hafalan-hafalan para penghafal. Mengulang atau membaca hafalan didepan orang lain ataupun guru, akan meninggalkan bekas hafalan dalam hati yang jauh lebih baik 
melebihi membaca atau mengulang hafalan sendirian lima kali lipat bahkan lebih (Al-Hafidz, 2006).

Masalah muraja'ah bergantung pada banyaknya hafalan yang dimiliki seseorang dan bagus tidaknya hafalan. Orang yang mempunyai hafalan bagus, dapat mengulang sebanyak seperdelapan dari hafalannya sekali waktu dan tidak boleh melebihi itu. Bagi orang hafalannya lemah, cukup dengan mengulang satu halaman saja hingga benar-benar bagus.

Setelah itu barulah ia boleh pindah kehalaman berikutnya. Kemudian apabila ingin mengulang dihadapan guru atau kyai, harus benar-benar bagus hafalannya dulu (tanpa ada sedikitpun kesalahan). Bagi seorang guru, jangan sekali-kali mengijinkan siswa mengulang di hadapannya kecuali dengan tidak ada sedikit pun kesalahan (Qori, 1998). Pada dasarnya kemampuan seseorang itu berbeda-beda, apabila kemampuannya lemah, ia boleh mengulang hanya setengah juz per hari. Adapun bagi mereka yang berkemampuan sedang, otomatis harus lebih banyak dari yang sebelumnya. Begitu pula bagi yang berkemampuan kuat harus melebihi keduanya. Sebagai catatan, semua yang kami sebutkan itu, tidak dapat lepas dari tangan guru atau kyainya. Gurulah yang berhak menentukan semua itu dengan melihat kemampuan masingmasing (Al-Hafidz, 2006).

\section{Implemetasi menghafal Al-Quran dengan metode muraja'ah di LPTQ Kabupaten Siak.}

Setoran (muraja'ah) hafalan baru kepada guru (ustadz/ustadzah). Dalam muraja'ah hafalan baru kepada ustadz/ustadzah diharapkan para siswa untuk setiap hari setor kepada ustadz/ustadzah. Hal ini diupayakan supaya santri cepat mempunyai hafalan banyak dan bisa khatam 30 juz sesuai target yang telah ditentukan baik target dari ustadz/ustadzah maupun target yang telah ditentukan dari siswa sendiri. Namun dalam realitanya, tidak seluruh siswa setor muraja'ah hafalan baru kepada ustadz/ustadzah setiap harinya. Hal ini dikarenakan kemampuan menghafal santri berbeda, ada siswa yang meskipun banyak tugas sekolah ia tetap bisa setiap hari setor muraja'ah hafalan baru, dan sebaliknya ada santri yang kemapuan hafalannya agak sulit jika disambi dengan banyaknya tugas dari sekolah.

Muraja'ah hafalan baru disesuaikan dengan kemampuan para siswa. mengingat kondisi siswa yang mayoritas usia dini dan seluruh siswa adalah pelajar. Ustadz/ustadzah bertugas memotivasi terus menerus terhadap santri agar santri tetap mempunyai kemauan akan hafalan Al-Quran. Yahya Abdul Fattah Az Zawawi mengatakan kepada calon penghafal Al-Quran dalam bukunya metode praktis cepat hafal Al-Quran bahwa: "Selama Anda dapat menemukan guru mengaji yang ahli atau Qari' yang bagus bacaannya, maka hal itu akan sangat bagus. Guru tersebut dapat mendengarkan bacaan Anda dan membenarkan kesalahan Anda serta mengajari Anda tentang ilmu tajwid."

Muraja'ah hafalan lama yang disemakkan oleh teman dilakasanakan setiap hari disetorkan kepada ustadz/ustadzah baik sebelum menambah hafalan baru ataupun sesud ah menambah hafalan baru. Hal tersebut dilakukan agar hafalan santri tetap terjaga, lancar, tidak ada salah atau kekeliruan hafalan 
baik dari segi makhraj maupun tajwidnya. Hasil hafalan menunjukkan semua santri lancar menghafal, tetapi makhraj dan tajwidnya belum tertata rapi karena temannya juga belum berani membenarkan makhraj maupun tajwidnya.

Menurut peneliti, muraja'ah yang dilakukan dengan disemakkan temannya sangat membantu kelancaran santri menghafal AI-Quran, sedangkan makhraj dan tajwidnya karena disemakkan oleh teman santri belum membantu kefashihan menghafal. Diperlukan proses menghafal tambahan baru yang disemakkan oleh ustadz/ustadzah yang memerhatikan makhraj dan tajwid, agar hasil menghafal santri benar-benar lancar dan fashih.

Yahya Abdul Fattah Az Zawawi mengatakan kepada calon penghafal AlQuran dalam bukunya metode praktis cepat hafal Al-Quran bahwa: "Selama Anda dapat menemukan orang yang baik untuk dijadikan teman dalam menghafal Al-Qur'an bersama Anda, maka hal itu akan sangat membantu. Usahakan mencari teman yang yang setara atau lebih baik dari kemampuan Anda. Hal ini akan sangat bermanfaat bagi diri Anda, diantaranya Anda memiliki teman yang senasib sepenanggungan. Teman yang ikhlash karena Allah, mencintai Anda, dan Anda pun mencintainya karena Allah. la akan bersama Anda karena Allah dan berpisah dengan Anda juga karena Allah. la juga menjadi penolong dan penyemangat bagi diri Anda, sebaliknya, Anda juga menjadi penolong dan penyemangat baginya untuk menghafal Al-Qur'an dan tetap konsisten. Anda dapat mendengarkan hafalannya dan ia pun jugadapat. mendengarkan hafalan Anda,sehingga Anda berdua dapat saling membenarkan apabila ada kesalahan"

Kegiatan muraja'ah hafalan lama yang langsung disemak oleh ustadz/ustadzah dilaksanakan setiap hari sebelum muraja'ah hafalan baru dimulai. Hal ini diupayakan agar kelancaran hafalan santri tetap terjaga, benar, dan baik makhraj serta tajwidnya. Namun realitanya, masih banyak santri yang belum tertata makhraj dan tajwidnya dikarenakan belum membiasakan pembenaran makhraj dan tajwidnya sejak awal proses menghafal.

Muraja'ah hafalan lama yang disemakkan oleh ustadz/ustadzah merupakan salah satu upaya untuk melestarikan hafalan Al-Quran santri agar tetap lancar, baik, dan benar makhraj dan tajwidnya. Ustadz/ustadzah mengelompokkan santri yang belum benar dan baik makhraj dan tajwidnya dengan diberikannya pengajaran dan agar tidak ketinggalan dengan santrilainnya. Hal ini bisa dikarenakan karena kemampuan lisan santri juga berbeda-beda.

\section{SIMPULAN}

Proses menghafal AI-Quran di LPTQ Kabupaten Siak menggunakan sistem One Day One Ayah (1 hari 1 ayat) yang disertai lagu tartil. Proses menghafal Al-Quran tentunya harus selalu diiringi niat yang ikhlas, meminta izin kepada orang tua, mempunyai tekad yang besar dan kuat, istiqamah, sehingga menjadi lancar membaca Al-Quran. Cara yang dapat digunakan untuk 
menghafal Al-Quran adalah dengan setoran (muraja'ah) hafalan baru kepada guru (ustadz/ustadzah), muraja'ah hafalan lama yang disemakkan teman dengan berhadapan dua orang dua orang, muraja'ah hafalan lama kepada ustadz/ustadzah, dan Al-Imtihan Fii Muraja'atil Muhafadlah (ujian mengulang hafalan).

\section{REFERENSI}

Al-Hafidz, M. J. (2006). Menghafal Al-Qur'an itu Mudah. Lamongan : CV Angkasa.

Fajarini, A., Sutoyo, A., \& Sugiharto, D. Y. (2017). Model Menghafal pada Penghafal Al-Qur'an Implikasinya pada Layanan Penguasaan Konten dalam Bimbingan dan Konseling. Jurnal Bimbingan Konseling Vol. 6 No. 1, 13-19. https://journal.unnes.ac.id/sju/index.php/jubk/article/view/17429

Keswara, I. (2017). Pengelolaan Pembelajaran Tahfidzul Qur'an ( Menghafal AlQuran) di Pondok Pesantren AL Husain Magelang. Jurnal Hanata Widya Vol. 6 No. 2 , 62-73.

http://journal.student.uny.ac.id/ojs/index.php/fipmp/article/view/7222

Qori, M. T. (1998). Cara Mudah Menghafal Al-Qur'an. Jakarta: Gema Insani.

Ra'uf, A. A., \& Al-Hafidz. (2009). Anda Pun Bisa Menjadi Hafidz Al-Qur'an. Jakarta: Markas Al-Qur'an.

Saptadi, H. (2012). Faktor-Faktor Pendukung Kemampuan Menghafal Al-Quran dan Implikasinya dalam Bimbingan dan Konseling. Jurnal Bimbingan Konseling Vol. 1 No. 2, 117-121. https://journal.unnes.ac.id/sju/ index.php/jubk/article/view/853

Shihab, M. Q. (2003). Wawasan Al-Qur'an. Bandung: Mizan.

Syamsudin, S. (2001). Metodologi Living Qur'an dan Hadist. Yogyakarta: Teras.

Wahid, W. A. (2012). Cara Cepat Bisa Menghafal Al-Qur'an. Yogyakarta: Diva Press.

Zawawie, M. (2011). P-M3 Al-Qur'an Pedoman Membaca, Mendengar, dan Menghafal Al-Qur'an. Solo: Tinta Medina.

Zen, M. (1985). Tata Cara/Problematika Menghafal Al-Qur'an dan PetunjukPetunjuknya. Jakarta: PT Maha Grafindo. 